\title{
Comparative study of Pap smear abnormalities in HIV infected and HIV non-infected women
}

\author{
Kusumam V. N.*, Naseema Beevi A., Smitha Sreenivas, Nurul Ameen A. M., Vidya R. Menon
}

Department of Obstetrics and Gynaecology, Government Medical College, Kozhikode, Kerala, India

Received: 14 January 2016

Revised: 01 February 2016

Accepted: 08 February 2016

\section{*Correspondence:}

Dr. Kusumam V. N.,

E-mail: chalilbhaskaran@yahoo.com

Copyright: $\odot$ the author(s), publisher and licensee Medip Academy. This is an open-access article distributed under the terms of the Creative Commons Attribution Non-Commercial License, which permits unrestricted non-commercial use, distribution, and reproduction in any medium, provided the original work is properly cited.

\begin{abstract}
Background: HIV positive women are more likely than HIV negative women to have cervical dysplasia. Incidence of HPV-related dysplasia increases as immune function declines. To analyse the prevalence of cervical dysplasia on papsmear among women affected with HIV and to compare with that of HIV negative women.

Methods: The study period was of 6 months duration from December 2010 to May 2011. Cervical cytology specimen from HIV positive and HIV negative women who attended the OPD of Institute of Maternal and Child Health, Government Medical College, Kozhikode. Were collected after excluding known case of carcinoma cervix, post hysterectomy patients, patients with bleeding per vagina and also those with active genital tract infections.

Results: A prospective study of 200 females (100 HIV positive and 100 HIV negative) was done in our hospital. Age range was between 36 and 50 years. PAP smear abnormality was obtained in $35 \%$ of the study group. Out of which $21 \%$ was seen in HIV positive patients and $14 \%$ in HIV negative patients. Prevalence of LSIL (low grade squamous intraepithelial lesion) was significantly higher among HIV positive patients. Abnormality was not associated with CD4 count, HIV status of husband or addictions of husband, not associated with number of partners of husband both in HIV positive and negative patients.

Conclusions: PAP smear abnormality (overall), prevalence of LSIL was significantly higher among HIV positive patients. It was not associated with SES, age of first intercourse, number of partners of wife and other immunosuppressive status.
\end{abstract}

Keywords: PAP smear abnormalities, HIV infection, Cervical dysplasia

\section{INTRODUCTION}

The concept of preinvasive disease of the cervix was introduced in 1947, when it was recognized that epithelial changes could be identified that had the appearance of invasive cancer but were confined to the epithelium. ${ }^{1}$ Subsequent studies showed that if these lesions were not treated, they can progress to cervical cancer. Cervical dysplasia is the term used to describe abnormal cells on the cervix. On a PAP smear report, dysplasia is referred to as cervical intraepithelial neoplasia (CIN) or squamous intraepithelial lesion (SIL). Cervical dysplasia is usually first discovered by PAP smear, where cells are swabbed from in and around the cervical os (opening of the cervix). ${ }^{2}$ It has been reported that HIV positive women are more likely than HIV negative women to have cervical dysplasia. Studies comparing HIV positive and HIV negative women with documentation of dysplasia by colposcopy revealed 5 times as many HIV positive as HIV negative women with disease. Cervical dysplsia and cancer are strongly associated with specific subtypes of the sexually transmitted virus called HPV (human papilloma virus). HIV positive women have a high rate of persistent HPV infections, and a higher rate than HIV negative women with the types of HPV that are 
associated with the development of high grade dysplasia and cervical cancer. Incidence of HPV-related dysplasia increases as immune function declines. The documentation of increased rates of cervical dysplasia prompted the CDC to add invasive cervical cancer to the AIDS surveillance case definition in 1993.

Dysplastic changes on PAP smear rated as low or high grade, high grade lesions considered precursors to cervical cancer, while the significance of low grade dysplasia has not been established. ${ }^{3}$ Studies comparing HIV positive and HIV negative women with documentation of dysplasia by colposcopy revealed 5 times as many HIV positive as HIV negative women with disease. A comparative study of Pap smear findings among HIV positive and negative women at Government Hospital of Thoracic Medicine (GHTM), Tambaram showed a high percentage of inflammatory Pap smears (51.96\%) among HIV positives. Hence these patients will require a follow up Pap smear and colposcopy and biopsy if inflammation is persistent to exclude cervical cancer. ${ }^{7}$

\section{METHODS}

The study period was of 6 months duration from December 2010 to May 2011. Cervical cytology specimen (PAP smear) was taken from HIV positive and HIV negative women who attended the OPD of Department of Obstetrics and Gynecology, Institute of Maternal and Child Health, Government Medical College, Kozhikode a tertiary level referral center. This was a descriptive study with a control group. We conducted this study from the patients who attended the ART clinic and OPD of Department of Obstetrics and Gynecology, IMCH, Govt. Medical College, Kozhikode from December 2010 to May 2011.

Cervical cytology taken from both HIV positive and HIV negative women for age more than 16 years after excluding known case of carcinoma cervix, post hysterectomy patients, patients with bleeding per vagina and also those with active genital tract infections.

\section{RESULTS}

In the study population $27 \%$ of patients were in the age group of $21-35$ years $(77.8 \%$ HIV positive and $22.2 \%$ HIV negative), $57 \%$ in $36-50$ years $(45.6 \%$ HIV positive and $54.4 \%$ HIV negative) and $16 \%$ in $>50$ years $(18.8 \%$ HIV positive and $81.2 \%$ HIV negative).

Among the population $75 \%$ were BPL (58.9\% HIV positive and $41.1 \%$ HIV negative) and $25 \%$ APL (22.4\% HIV positive and $77.6 \%$ HIV negative).

Considering immunosuppressive status, $17 \%$ were immunosuppressed (23.5\% HIV positive and $76.5 \%$ HIV negative) and $83 \%$ were without immunosuppression (55.4\% HIV positive and 44.6\% HIV negative).

$12 \%$ of patients were addicted and $88 \%$ were not addicted (Table 1).

Table 1: Association of PAP smear abnormalities and socioeconomic status.

\begin{tabular}{|c|c|c|c|c|c|c|}
\hline \multirow{2}{*}{ HIV status } & \multirow{2}{*}{ HIV status } & & & \multicolumn{2}{|l|}{ SES } & \multirow{2}{*}{ Total } \\
\hline & & & & APL & BPL & \\
\hline \multirow{3}{*}{ Positive } & \multirow[t]{2}{*}{ PAP smear } & Normal & $\begin{array}{l}\text { Number } \\
\%\end{array}$ & $\begin{array}{l}4 \\
6.9 \%\end{array}$ & $\begin{array}{l}54 \\
93.1 \%\end{array}$ & $\begin{array}{l}58 \\
100.0 \%\end{array}$ \\
\hline & & Abnormal & $\begin{array}{l}\text { Number } \\
\%\end{array}$ & $\begin{array}{l}7 \\
16.7 \%\end{array}$ & $\begin{array}{l}35 \\
83.3 \%\end{array}$ & $\begin{array}{l}42 \\
100.0 \%\end{array}$ \\
\hline & Total & & $\begin{array}{l}\text { Number } \\
\%\end{array}$ & $\begin{array}{l}11 \\
11.0 \%\end{array}$ & $\begin{array}{l}89 \\
89.0 \%\end{array}$ & $\begin{array}{l}100 \\
100.0 \%\end{array}$ \\
\hline \multirow{3}{*}{ Negative } & \multirow[t]{2}{*}{ PAP smear } & Normal & $\begin{array}{l}\text { Number } \\
\%\end{array}$ & $\begin{array}{l}27 \\
37.5 \%\end{array}$ & $\begin{array}{l}45 \\
62.5 \%\end{array}$ & $\begin{array}{l}72 \\
100.0 \%\end{array}$ \\
\hline & & Abnormal & $\begin{array}{l}\text { Number } \\
\%\end{array}$ & $\begin{array}{l}11 \\
39.3 \%\end{array}$ & $\begin{array}{l}17 \\
60.7 \%\end{array}$ & $\begin{array}{l}28 \\
100.0 \%\end{array}$ \\
\hline & \multicolumn{2}{|l|}{ Total } & $\begin{array}{l}\text { Number } \\
\%\end{array}$ & $\begin{array}{l}38 \\
38.0 \%\end{array}$ & $\begin{array}{l}62 \\
62.0 \%\end{array}$ & $\begin{array}{l}100 \\
100.0 \%\end{array}$ \\
\hline
\end{tabular}

Pap smear abnormality was not associated with SES both in HIV positive and negative patients, $\mathrm{p}=0.194$ and $\mathrm{p}=0.869$ respectively.

$85 \%$ of the study group were less than or equal to para 3 (55.6\% HIV positive and $44.4 \%$ HIV negative) and $15 \%$ more than para $3(19.4 \%$ HIV positive and $80.6 \%$ HIV negative).
In the study group, $43 \%$ used any form of contraception and $57 \%$ without (Table 2). Prevalence of HIV more among those not using any contraception. OR $=1.09(0-$ 6-1.97), $\mathrm{p}=0.755$. 
Table 2: PAP smear abnormalities and number of partners.

\begin{tabular}{|c|c|c|c|c|c|c|}
\hline \multirow{2}{*}{ HIV Status } & & & & \multicolumn{2}{|c|}{ Wife partners } & \multirow{2}{*}{ Total } \\
\hline & & & & Single & Multiple & \\
\hline \multirow{3}{*}{ Positive } & PAP Smear & Normal & $\begin{array}{l}\text { Number } \\
\%\end{array}$ & $\begin{array}{l}55 \\
94.8 \%\end{array}$ & $\begin{array}{l}3 \\
5.2 \%\end{array}$ & $\begin{array}{l}58 \\
100.0 \%\end{array}$ \\
\hline & & Abnormal & $\begin{array}{l}\text { Number } \\
\%\end{array}$ & $\begin{array}{l}38 \\
90.5 \%\end{array}$ & $\begin{array}{l}4 \\
9.5 \%\end{array}$ & $\begin{array}{l}42 \\
100.0 \%\end{array}$ \\
\hline & Total & & $\begin{array}{l}\text { Number } \\
\%\end{array}$ & $\begin{array}{l}93 \\
93.0 \%\end{array}$ & $\begin{array}{l}7 \\
7.0 \%\end{array}$ & $\begin{array}{l}100 \\
100.0 \%\end{array}$ \\
\hline \multirow{3}{*}{ Negative } & PAP Smear & Normal & $\begin{array}{l}\text { Number } \\
\%\end{array}$ & $\begin{array}{l}71 \\
98.6 \%\end{array}$ & $\begin{array}{l}1 \\
1.4 \%\end{array}$ & $\begin{array}{l}72 \\
100.0 \%\end{array}$ \\
\hline & & Abnormal & $\begin{array}{l}\text { Number } \\
\%\end{array}$ & $\begin{array}{l}27 \\
96.4 \%\end{array}$ & $\begin{array}{l}1 \\
3.6 \%\end{array}$ & $\begin{array}{l}28 \\
100.0 \%\end{array}$ \\
\hline & Total & & $\begin{array}{l}\text { Number } \\
\%\end{array}$ & $\begin{array}{l}98 \\
98.0 \%\end{array}$ & $\begin{array}{l}2 \\
2.0 \%\end{array}$ & $\begin{array}{l}100 \\
100.0 \%\end{array}$ \\
\hline
\end{tabular}

Pap smear abnormality was not associated with number of partners of wife both in HIV positive and negative patients, $\mathrm{p}=0.449$ and $\mathrm{p}=0.484$ respectively.

Table 3: Types of PAP smear abnormalities.

\begin{tabular}{|c|c|c|c|c|c|c|c|c|}
\hline & & & \multicolumn{6}{|c|}{ PAP smear } \\
\hline & & & NILM & $\begin{array}{l}\text { Inflammatory } \\
\text { smear }\end{array}$ & ASCUS & LSIL & $\begin{array}{l}\text { Squamous } \\
\text { cell } \\
\text { carcinoma }\end{array}$ & Total \\
\hline \multirow{4}{*}{$\begin{array}{l}\text { HIV } \\
\text { Status }\end{array}$} & \multirow{2}{*}{ Positive } & Number & 58 & 30 & 1 & 9 & 2 & 100 \\
\hline & & $\%$ within PAP smear & $44.6 \%$ & $54.5 \%$ & $50.0 \%$ & $81.8 \%$ & $100.0 \%$ & $50.0 \%$ \\
\hline & \multirow{2}{*}{ Negative } & Number & 72 & 25 & 1 & 2 & 0 & 100 \\
\hline & & $\%$ within PAP smear & $55.4 \%$ & $45.5 \%$ & $50.0 \%$ & $18.2 \%$ & $0.0 \%$ & $50.0 \%$ \\
\hline \multirow{2}{*}{\multicolumn{3}{|c|}{$\begin{array}{l}\text { Total number } \\
\% \text { within PAP smear }\end{array}$}} & 130 & 55 & 2 & 11 & 2 & 200 \\
\hline & & & $100 \%$ & $100 \%$ & $100 \%$ & $100 \%$ & $100 \%$ & $100 \%$ \\
\hline
\end{tabular}

Pap smear abnormality (overall) was significantly higher among HIV positive (42\%) patients, compared to that in HIV negative (28\%) patients, $\mathrm{RR}=1.5 \quad(1.02-2.21)$, $\mathrm{p}=0.038$.

Prevalence of inflammatory smear was not significantly different between HIV positive and negative patients, $\mathrm{RR}=1.2$ (0.76-1.89), $\mathrm{p}=0.428$.

Prevalence of ASCUS was not significantly different between HIV positive and negative patients, $\mathrm{RR}=1.00$ (0.06-15.77), $\mathrm{p}=0.751$.

Prevalence of LSIL was significantly higher among HIV positive patients, $\mathrm{RR}=4.5(1.00-20.31), \mathrm{p}=0.03$.

Prevalence of squamous cell carcinoma was not significantly different between HIV positive and negative patients, $\mathrm{p}=0.249$.

$78 \%$ of patients had various complaints like discharge $\mathrm{P} / \mathrm{V}$ and post coital bleeding and $22 \%$ of patients were without any complaints (Table 3 ).
Among the study population of Husbands $50 \%$ were HIV positive.

$47 \%$ of husbands who were addicted to alcohol had $70.2 \%$ positive HIV status in wife and $53 \%$ of husbands who were not addicted to alcohol had $31.4 \%$ positive HIV status in wife.

In the $49 \%$ of single partner husband $(3.09 \%$ were HIV positive and $96.9 \%$ were HIV negative wives) and $51 \%$ with multiple partner husband $(94.2 \%$ were HIV positive and $5.8 \%$ HIV negative wives).

Table 4: PAP smear abnormality and ART.

\begin{tabular}{|llll|}
\hline $\begin{array}{l}\text { HIV } \\
\text { status } \\
\text { Positive }\end{array}$ & Yes & No & Total \\
\hline Normal & $44(75.9 \%)$ & $14(24.1 \%)$ & $58(100 \%)$ \\
\hline Abnormal & $36(85.7 \%)$ & $6(14.3 \%)$ & $42(100 \%)$ \\
\hline Total & $80(80 \%)$ & $20(20 \%)$ & $100(100 \%)$ \\
\hline
\end{tabular}


Out of the total study population who were with HIV positive status, $5.2 \%$ of multiple wife partners had normal PAP smear and $9.5 \%$ had abnormal pap smear.

Out of $100 \mathrm{HIV}$ positive populations, $80 \%$ were on ART (Table 4).

CD4 count was done in all $100 \mathrm{HIV}$ positive patients. There was no significant relationship between PAP smear and CD4 counts.

\section{DISCUSSION}

The incidence of HIV is on the rise. ${ }^{1}$ As per HIV estimates 2008-09, there are an estimated 23.9 lakh people living with HIV / AIDS in India with an adult prevalence of 0.31 percent in 2009 (NACO report 2011).

HIV positive women have a high rate of persistent HPV infections, and a higher rate than HIV negative women with the types of HPV that are associated with the development of high grade dysplasia and cervical cancer. $^{2}$

This study enrolled 200 patients screened for inclusion. All the patients in the study population were of South Indian ethnicity.

In my study it was found that PAP abnormality is significantly higher in HIV positive women than HIV negative women (42\% versus $28 \%$ ). This result is comparable with recent study of Seethalakshmi et al $(58.8 \%$ versus $43.75 \%)$ and that of O'Sullivan MJ et al. ${ }^{7}$ Seven studies from Europe, the United States and Africa have provided figures that can be compared, and show highly concordant results: prevalence rates of abnormal PAP smear in these studies ranged from $10 \%$ to $24 \%$ among HIV positive women, from 4 to $10 \%$ amongst HIV negative women. ${ }^{3}$ Prevalence of different types of PAP smear abnormalities in my study were; inflammatory smear (20\%), ASCUS (1\%), LSIL (9\%) and SCC (2\%) among HIV positive women. (25\%, $1 \%$, $2 \%$ and 0 respectively in HIV negative).

Other risk factors associated with HIV was considered in the study viz; number of partners, addictions, method of contraception etc, but no significant association was found. ${ }^{4}$

In the present study $26.2 \%$ cases with CD4 count less than $200 / \mu \mathrm{L}$ were obtained compared to Amphan et al $28.87 \%$, Leibenson et al $39.75 \%$, Jennifer et al $92.67 \%$ and BM Jha et al $10.46 \%$ cases. $^{5}$

In the present study $42 \%$ cases with epithelial abnormalities were detected which was high against the incidence found by Amphan et al 15.4\%, Leibenson et al $20.24 \%$, Jennifer et al $66.3 \%$ and BM Jha et al $8.68 \%{ }^{6}$
Considering ASCUS, our study shows only $1 \%$ which is very low compared to Amphan et al $2.8 \%$, Jennifer et al $15.3 \%$ and BM Jha et al 3.19\%.

In relation to LSIL, our study reveals $9 \%$ compared to Amphan et al $8.5 \%$, Leibenson et al $19.05 \%$, Jennifer et al $40 \%$ and BM Jha $2.7 \%{ }^{8}$

Our study reveals $58 \%$ with no epithelial cell abnromalities compared to Amphan et al 84.6\%, Leibenson et al $79.6 \%$, Jennifer et al $34.5 \%$ and BM Jha et al $87.89 \%$.

The incidence of epithelial abnormalities increases with the more number of cases showing CD4 count less than $200 / \mu \mathrm{L}$ and the present study did not find any significant relation between CD4 count and epithelial abnormality.

$\mathrm{P}$ value in present study was $<0.05$. It signifies that the difference is statistically significant and signifies that HIV infected women have more risk of having cervical epithelial abnormalities as compared to general population.

\section{Limitations}

This study had a small sample size which might not have been adequate for discerning associations between all the various factors in the genesis and evolution of PAP smear abnormalities.

Since further follow-up was not incorporated into the study design, prognostic and mortality statistics could not be collected.

\section{CONCLUSIONS}

PAP smear abnormality (overall), prevalence of LSIL was significantly higher among HIV positive patients. It was not associated with parity, socioeconomic strata, number of partners of wife, immunosuppressive status, age group and method of contraception and HIV status of husband.

\section{ACKNOWLEDGEMENTS}

Patients who participated in the study.

Funding: No funding sources

Conflict of interest: None declared

Ethical approval: The study was approved by the Institutional Ethics Committee

\section{REFERENCES}

1. Berek JS. Intraepithelial Disease of Cervix, vagina and vulva. Berek and Novak's Gynaecology: 14th edition. 2014:562-89. 
2. Pund ER, Nieburgs H, Nettles JB. Preinvasive carcinoma of the cervix uteri. Arch Pathol Lab Med 1947;44:571-7.

3. American College of Obstetricians and Gynecologists. Cervical cytology screening. ACOG Practice Bulletin. Number 45, August 2003. Int J Gynaecol Obstet. 2003.

4. ASCUS-LSIL Triage Study (ALTS) Group. Results of a randomized trial on the management of cytology interpretations of atypical squamous cell of undetermined significance. Am J Obstet Gynecol. 2003;188(6):1383-92.

5. ACOG Committee on Practice Bulletins Gyceology. ACOG Practice Bulletin No.109. Cervical Cytology screening. Obstet Gynecol. 2009.

6. American College of Obstetricians and Gynecologists. ACOG Committee Opinion No.463:
Cervical cancer in adolescents: screening, evaluation and management. Obstet Gynecol. 2010.

7. Seethalakshmi GV. A comparative study of PAP smear findings among the HIV positive and negative women at Government Hospital of Thoracic Medicine (GHTM), Tambaram. BMC Infectious Diseases. 2012;12(1):P35.

8. BM Jha, Patel M. A study on cervical PAP smear examination in patients living with HIV. National Journal of Medical Research. 2012;2(1):81-4.

Cite this article as: Kusumam VN, Beevi NA, Sreenivas S, Nurul AAM, Menon VR. Comparative study of Pap smear abnormalities in HIV infected and HIV non-infected women. Int J Reprod Contracept Obstet Gynecol 2016;5:783-7. 